\title{
SIKAP DAN PERILAKU BELANJA KONSUMEN MINYAK GORENG KEMASAN DI KECAMATAN PANGKALAN KERINCI KABUPATEN PELALAWAN
}

\author{
SONIA MAGDALENA, YENI KUSUMAWATY, EVY MAHARANI \\ Jurusan Agribisnis Fakultas Universitas Riau \\ Kampus Binawidya Simpang Baru Kecamatan Tampan Pekanbaru \\ Email : soniamagdalena133@gmail.com
}

\begin{abstract}
ABSTRAK
Beredarnya berbagai macam dan ukuran produk minyak goreng kemasan yang semakin gencar di tawarkan membuat konsumen memiliki banyak pilihan dalam melakukan pembelian. Penelitian ini bertujuan untuk menganalisis sikap dan perilaku belaja konsumen minyak goreng kemasan di Kecamatan Pangkalan Kerinci Kabupaten Pelalawan. Pemilihan Kabupaten Pelalawan dengan pertimbangan lokasi ini merupakan kabupaten yang menempati peringkat keempat dalam produksi kelapa sawit di Provinsi Riau. Pemilihan lokasi Kecamatan Pangkalan Kerinci berdasarkan atas pertimbangan Kecamatan Pangkalan Kerinci sudah mewakili jawaban dari seluruh konsumen minyak goreng dari setiap kecamatan untuk mengkaji perilaku belanja konsumen di wilayah kecamatan karena terdapat ritel-ritel yang lengkap dengan akses yang mudah untuk dikunjungi konsumen. Responden dalam penelitian ini merupakan responden yang sedang berbelanja di lokasi belanja seperti grosir, hypermarket, minimarket, swalayan, pasar tradisional,dan warung yang terdapat di Kecamatan Pangkalan Kerinci Kabupaten Pelalawan. Teknik pengambilan responden menggunakan mall-intercept. Metode analisis data yang digunakan adalah model sikap Fishbein, model norma subjektif, dan model theory of reasoned action (TRA). Sikap belanja konsumen minyak goreng kemasan di Kecamatan Pangkalan Kerinci Kabupaten Pelalawan bernilai positif dengan nilai 17.22 dan secara keseluruhan sikap konsumen terhadap atribut produk minyak goreng kemasan mempunyai sikap yang cukup baik. Perilaku belanja konsumen minyak goreng kemasan di Kecamatan Pangkalan Kerinci Kabupaten Pelalawan bernilai positif dengan nilai sebesar 1,369.97 yang berarti bahwa perilaku pembelian konsumen terhadap minyak goreng kemasan adalah baik.
\end{abstract}

Kata Kunci : Konsumen, Minyak Goreng Kemasan, Perilaku, Sikap

\section{PENDAHULUAN}

Subsektor perkebunan merupakan salah satu sub sektor pertanian yang memberikan kontribusi terbesar bagi produk domestik bruto (PDB) Indonesia. Kelapa sawit adalah salah satu komuditas perkebunan yang merupakan tanaman primadona untuk dikembangkan baik pada industri hulu maupun hilir. Berdasarkan data Dirjen Perkebunan Kementerian Pertanian (2016) tanaman kelapa sawit memberikan sumbangsih sebesar Rp.429.000.000.000.000 terhadap PDB nasional.

51 I Sikap Dan Perilaku Belanja Konsumen Minyak Goreng Kemasan Di Kecamatan Pangkalan Kerinci Kabupaten Pelalawan 
Provinsi Riau merupakan sentra perkebunan kelapa sawit terbesar di Indonesia dengan luas areal dan produksi sebesar $25,94 \%$ dari total luas areal dan produksi kelapa sawit di Indonesia. Kabupaten Pelalawan merupakan kabupaten dengan peringkat keempat terbesar sentra produksi minyak sawit di Riau (Direktorat Jendral Perkebunan, 2016). Menurut Rondang (2006) kelapa sawit menghasilkan dua macam minyak yang berlainan sifatnya, yaitu minyak sawit mentah/crude palm oil (CPO) yang berasal dari sabut atau daging kelapa sawit dan minyak inti sawit/palm kernel oil (PKO) yang berasal dari inti buah sawit.

Minyak kelapa sawit memiliki keunggulan komparatif antara lain, selain diolah menjadi bahan baku minyak goreng, minyak kelapa sawit dapat juga diolah menjadi bahan baku lainnya seperti sabun dan alat komestik, minyak kelapa sawit juga memiliki harga bahan baku termurah dibandingkan dengan bahan baku yang lain seperti minyak lobak, kedelai, dan bunga matahari sementara tingkat keunggulan bagi produsen tetap tinggi. Keunggulan komparatif tersebut telah membuktikan prospek kelapa sawit yang bagus dalam jangka panjang (Fauzi, 2008). Minyak goreng berbahan dasar kelapa sawit memiliki keunggulan dibandingkan minyak nabati lainnya, seperti memiliki kadar kolesterol yang rendah, bukan tanpa kolesterol.

Industri minyak goreng sawit dalam negeri terbagi menjadi dua, yaitu minyak goreng curah dan minyak goreng kemasan. Perbedaan minyak goreng curah dan minyak goreng kemasan terletak pada proses penyaringan yang berpengaruh terhadap kualitas minyak goreng. Minyak goreng kemasan mengalami dua kali penyaringan sedangkan minyak goreng curah mengalami satu kali penyaringan (Kukuh, 2010). Keputusan konsumen dalam mengkonsumsi minyak goreng baik curah maupun kemasan dipengaruhi oleh banyak faktor, menurut Kotler dan Armstrong (2001) faktor yang mempengaruhi perilaku konsumen ialah faktor kebudayaan, faktor sosial, faktor pribadi dan faktor psikologis.

Selain itu perilaku konsumen juga dipengaruhi oleh faktor- faktor yang tidak dapat dipengaruhi oleh pemasar, seperti dengan adanya kebijakan pemerintah mengenai minyak goreng wajib kemasan. Pemerintah memiliki peraturan yang sangat penting untuk diperhatikan oleh seluruh masyarakat yang mengkonsumsi minyak goreng curah. Peraturan pemerintah terkait penggunaan minyak goreng yaitu, larangan bagi masyarakat untuk menggunakan minyak goreng curah atau minyak goreng wajib kemasan. Kebijakan pemerintah mengenai minyak goreng wajib kemasan sebelumnya diatur dalam peraturan Menteri Perdagangan (Permendag) Nomor 80/MDag/PER/10/2014, dan mengalami perubahan menjadi peraturan menteri perdagangan (Permendag) Nomor 9/M-Dag/PER/2/2016. Kebijakan ini mewajibkan penggunaan minyak goreng wajib

\section{I Sikap Dan Perilaku Belanja Konsumen Minyak Goreng Kemasan Di Kecamatan} Pangkalan Kerinci Kabupaten Pelalawan 
kemasan untuk dikonsumsi oleh seluruh masyarakat Indonesia, dengan merek Minyakita (Primadhyta, 2016).

Minyak goreng kemasan merupakan jenis minyak goreng yang diukur dalam satuan volume (liter) dan dikemas dengan botol, plastik refill, dan jerigen. Walaupun minyak goreng curah masih terdapat dipasaran namun semakin banyak konsumen yang menggunakan minyak goreng kemasan (Supriyana, 2006). Beredarnya berbagai macam dan ukuran produk minyak goreng kemasan yang semakin gencar ditawarkan membuat konsumen memiliki banyak pilihan dalam melakukan pembelian. Penelitian ini bertujuan untuk mengetahui sikap dan perilaku belanja konsumen minyak goreng kemasan di Kecamatan Pangkalan Kerinci Kabupaten Pelalawan.

\section{METODE PENELITIAN}

Penelitian ini dilakukan di Kecamatan Pangkalan Kerinci Kabupaten Pelalawan. Pemilihan Kabupaten Pelalawan dengan pertimbangan bahwa lokasi ini merupakan kabupaten yang menempati peringkat keempat dalam produksi kelapa sawit di Provinsi Riau. Pemilihan Kecamatan Pangkalan Kerinci dikarenakan lokasi ini merupakan ibu kota Kabupaten Pelalawan. Kecamatan Pangkalan Kerinci juga sudah mewakili jawaban dari seluruh konsumen minyak goreng dari setiap kecamatan untuk mengkaji perilaku belanja konsumen diwilayah kecamatan karena terdapat ritelritel yang lengkap dengan akses yang mudah untuk dikunjungi konsumen. Penelitian ini dilaksanakan pada bulan Juni 2018 sampai bulan Februari 2019.

Metode penelitian yang digunakan adalah metode survei dengan cara wawancara dan mengisi kuesioner oleh responden. Populasi pada penelitian ini adalah seluruh konsumen yang menggunakan minyak goreng kemasan di Kecamatan Pangkalan Kerinci dan jumlah sampel penelitian yaitu 75 responden. Teknik pengambilan responden menggunakan mall-intercept, dimana peneliti dapat memiliki konsumen potensial dengan urutan kelipatan yang telah ditentukan dan langsung memberikan pertanyaan kepada responden yang berada dipusat perbelanjaan, memenuhi kriteria, dan bersedia diwawancarai mengenai sikap dan perilaku konsumen. Lokasi pengambilan responden terbagi dibeberapa tempat yaitu grosir, hypermarket, minimarket, swalayan, pasar tradisional,dan warung yang terdapat di Kecamatan Pangkalan Kerinci Kabupaten Pelalawan.

Data yang digunakan dalam penelitian ini adalah data primer dan data sekunder. Data primer adalah data yang diperoleh melalui observasi dan wawancara langsung dengan sampel (konsumen rumah tangga) di Kecamatan Pangkalan Kerinci Kabupaten Pelalawan. Data sekunder adalah data yang diperoleh dari peneliti dari sumber yang sudah ada. Data primer dalam penelitian ini berupa pernyataan konsumen mengenai keputusan pembelian konsumen terhadap minyak goreng kemasan

\section{I Sikap Dan Perilaku Belanja Konsumen Minyak Goreng Kemasan Di Kecamatan} Pangkalan Kerinci Kabupaten Pelalawan 
dan data sekunder yang diperlukan seperti gambaran umum tempat penelitian. Data dianalisis menggunakan analisis model sikap, analisis model norma subjektif, dan analisis perilaku.

\subsection{Analisis Model Sikap}

Analisis model sikap digunakan untuk menganalisis sikap konsumen terhadap pembelian minyak goreng kemasan di Kecamatan Pangkala Kerinci Kabupaten Pelalawan. rumus sebagai berikut :

$$
A B=\sum_{i=1}^{n} b_{i} e_{i}
$$

Model Analisis Fishbein (Umar, 2000)

Dalam hal ini $b_{i}$ dan $e_{i}$ masing-masing diperoleh dengan menggunakan rumus sebagai berikut :

$$
\begin{gathered}
b_{i}=\frac{\sum_{i=1}^{n} r_{i} f\left(x_{i}\right)}{n} \\
e_{i}=\frac{\sum_{i=1}^{n} r_{i} f\left(y_{i}\right)}{n}
\end{gathered}
$$

Keterangan :

$\mathrm{r}_{\mathrm{i}} \quad=$ Bobot skor ke- $\mathrm{i}$

$\mathrm{f}\left(\mathrm{x}_{\mathrm{i}}\right)$ = Jumlah responden yang memiliki bobot skor ke-i untuk variabel keyakinan $\left(\mathrm{b}_{\mathrm{i}}\right)$

$\mathrm{f}\left(\mathrm{y}_{\mathrm{i}}\right)$ = Jumlah responden yang memiliki bobot skor ke-i untuk variabel evaluasi $\left(\mathrm{e}_{\mathrm{i}}\right)$

$\mathrm{AB}=$ Sikap total individu terhadap atribut minyak goreng

$\mathrm{b}_{\mathrm{i}} \quad=$ Kekuatan keyakinan konsumen terhadap atribut minyak goreng

$\mathrm{e}_{\mathrm{i}} \quad=$ Evaluasi terhadap atribut minyak goreng

$\mathrm{n} \quad=$ Jumlah kriteria atribut minyak goreng yang relevan

Bobot $=\mathrm{a}: 3, \mathrm{~b}: 2, \mathrm{c}: 1, \mathrm{~d}:-1, \mathrm{e}:-2$, dan $\mathrm{f}:-3$

Variabel ini bersifat internal individu yang berkaitan langsung dengan objek penelitian dan atribut-atribut langsung serta memiliki peranan penting dalam pengukuran perilaku, karena menentukan tindakan apa yang akan dilakukan tanpa dipengaruhi faktor eksternal.

Variabel sikap menurut Fishbein terbagi menjadi dua yaitu variabel keyakinan dan variabel evaluasi (Umar, 2000). Dalam penelitian ini komponen atribut minyak goreng untuk analisis variabel keyakinan dan sikap adalah :

54 I Sikap Dan Perilaku Belanja Konsumen Minyak Goreng Kemasan Di Kecamatan Pangkalan Kerinci Kabupaten Pelalawan 
a. Atribut yang melekat pada minyak goreng seperti: harga yang murah, warna yang jernih, higienis, ukuran bervariasi, praktis, dan kandungan terjaga

b. Variabel keyakinan

c. Variabel evaluasi

Skor maksimum sikap konsumen terhadap minyak goreng dapat dilihat pada Tabel 1.

Tabel 1. Skor maksimum sikap konsumen

\begin{tabular}{clccc}
\hline No & $\begin{array}{l}\text { Atribut minyak goreng } \\
\text { kemasan }\end{array}$ & $\begin{array}{c}\text { Keyakinan Ideal } \\
(1)\end{array}$ & $\begin{array}{c}\text { Ei } \\
(2)\end{array}$ & $\begin{array}{c}\text { Total } \\
(1) \times(2)\end{array}$ \\
\hline 1 & Harga yang murah & 3 & 3 & 9 \\
2 & Warna yang jernih & 3 & 3 & 9 \\
3 & Higienis & 3 & 3 & 9 \\
4 & Ukuran bervariasi & 3 & 3 & 9 \\
5 & Praktis & 3 & 3 & 9 \\
6 & Kandungan terjaga & 3 & 3 & 9 \\
\hline \multicolumn{2}{c}{ Jumlah Skor Maksimum }
\end{tabular}

Penentuan nilai sikap berdasarkan skala sikap konsumen dimana keyakinan ideal dan evaluasi yang digunakan adalah bobot skor terbesar bernilai tiga sehingga diperoleh rentang skala sikap seperti pada Tabel 2 .

Tabel 2. Rentang skala sikap

\begin{tabular}{lcc}
\hline Sikap konsumen & Skor & Rentang Nilai \\
\hline Sangat Tidak Baik & -3 & $-54 \leq \mathrm{AB}<-36$ \\
Tidak Baik & -2 & $-36 \leq \mathrm{AB}<-18$ \\
Cukup Tidak Baik & -1 & $-18 \leq \mathrm{AB}<0$ \\
Netral & 0 & $\mathrm{AB}=0$ \\
Cukup Baik & 1 & $0<\mathrm{AB} \leq 18$ \\
Baik & 2 & $18<\mathrm{AB} \leq 36$ \\
Sangat Baik & 3 & $36<\mathrm{AB} \leq 54$ \\
\hline
\end{tabular}

Keterangan: $\mathrm{AB}=$ Sikap Kosumen

\subsection{Analisis Model Norma Subjektif}

Pengukuran perilaku konsumen diperlukan adanya faktor sikap konsumen dan norma subjektif. Norma subjektif merupakan faktor pendorong dalam berperilaku, yang terbentuk dari adanya keyakinan normatif dan motivasi untuk melakukan suatu tindakan. Pengukuran norma subjektif maka digunakan rumus sebagai berikut:

55 I Sikap Dan Perilaku Belanja Konsumen Minyak Goreng Kemasan Di Kecamatan Pangkalan Kerinci Kabupaten Pelalawan 


$$
\mathrm{SN}=\sum_{\mathrm{j}=1}^{\mathrm{n}} \mathrm{NB}_{\mathrm{j}} \mathrm{MC}_{\mathrm{j}}
$$

Model Analisis Fishbein (Umar, 2000)

Dalam hal ini $\mathrm{NB}_{\mathrm{j}}$ dan $\mathrm{MC}_{\mathrm{j}}$ masing-masing diperoleh dengan menggunakan rumus sebagai berikut :

$$
\begin{gathered}
N B_{\mathbf{j}}=\frac{\sum_{j=1}^{n} r_{j} f\left(x_{j}\right)}{n} \\
\text { dan } \\
M C_{\mathbf{j}}=\frac{\sum_{j=1}^{n} r_{j} f\left(\mathbf{y}_{j}\right)}{n}
\end{gathered}
$$

Keterangan :

SN = Norma Subjektif

$\mathrm{r}_{\mathrm{j}} \quad=$ Bobot skor ke-j

$\mathrm{f}\left(\mathrm{x}_{\mathrm{j}}\right)$ = Jumlah responden yang memiliki bobot skor ke-j untuk variabel keyakinan normatif $\left(\mathrm{NB}_{\mathrm{j}}\right)$

$\mathrm{f}\left(\mathrm{y}_{\mathrm{j}}\right)$ = Jumlah responden yang memiliki bobot skor ke-j untuk variabel motivasi $\left(\mathrm{MC}_{\mathrm{j}}\right)$

$\mathrm{NB}_{\mathrm{j}}=$ Keyakinan normatif individu

$\mathrm{MC}_{\mathrm{j}}=$ Motivasi dari referen

$\mathrm{N}=$ Jumlah referen yang relevan

Bobot $=\mathrm{a}: 3, \mathrm{~b}: 2, \mathrm{c}: 1, \mathrm{~d}:-1, \mathrm{e}:-2$, dan $\mathrm{f}:-3$

Variabel ini bersifat eksternal dan mempunyai pengaruh terhadap perilaku individu. Variabel ini menekankan bahwa referen masyarakat sekitar dan kebijakan pemerintah yang dipercaya berpengaruh terhadap keputusan konsumen dalam membeli minyak goreng.

Variabel norma subjektif menurut Fishbein terbagi menjadi dua :

a. Variabel keyakinan normatif, yaitu keyakinan normatif konsumen bahwa referen masyarakat sekitar dan kebijakan pemerintah yang berpendapat bahwa konsumen sebaiknya membeli minyak goreng

b. Variabel motivasi, yaitu motivasi konsumen untuk menuruti pendapat referen masyarakat sekitar dan kebijakan pemerintah untuk membeli minyak goreng

56 I Sikap Dan Perilaku Belanja Konsumen Minyak Goreng Kemasan Di Kecamatan Pangkalan Kerinci Kabupaten Pelalawan 
c. Komponen-komponen dari variabel keyakinan normatif dan variabel motivasi terdiri dari : masyarakat sekitar dan kebijakan pemerintah terhadap penggunaan minyak goreng wajib kemasan

\subsection{Analisis Sikap}

Analisis perilaku bertujuan untuk mengetahui perilaku konsumen terhadap pembelian minyak goreng kemasan di Kecamatan Pangkalan Kerinci Kabupaten Pelalawan. Pada penelitian ini, analisis perilaku dianalisis menggunakan theory of reasoned action (TRA). Analisis theory of reasoned action digambarkan dengan formula:

$$
\mathrm{B} \sim \mathrm{BI}=\mathrm{W}_{1}(\mathrm{Ab})+\mathrm{W}_{2}(\mathrm{SN})
$$

Keterangan :

$\mathrm{BI}=$ Perilaku konsumen (behaviour intention)

$\mathrm{Ab}=$ Sikap total individu terhadap atribut minyak goreng

$\mathrm{SN} \quad=$ Norma Subyektif

$\mathrm{W}_{1} \mathrm{~W}_{2}=$ Bobot yang ditemukan secara empiris, menggambarkan pengaruh relatif dari komponen .

Nilai $\mathrm{W}_{1}$ diperoleh dari perhitungan dan persentase pada jawaban negatif (-) dan nilai $\mathrm{W}_{2}$ diperoleh dari perhitungan dan persentase pada jawaban positif (+). Penjumlahan dari nilai $\mathrm{W}_{1}$ dan $\mathrm{W}_{2}$ ialah $100 \%$, sehingga jika hasil yang diperoleh nilai $\mathrm{W}_{1}>\mathrm{W}_{2}$ berarti pengambilan keputusan lebih banyak dilakukan berdasarkan keputusan individu atau konsumen sendiri. Jika hasil yang diperoleh $\mathrm{W}_{1}<\mathrm{W}_{2}$ maka pengambilan keputusan lebih banyak dilakukan karena pengaruh pihak lain.

Pada penelitan ini untuk menunjukan bagaimana sikap dan perilaku konsumen terhadap produk minyak goreng kemasan maka digunakan metode statistika deskriptif berdasarkan model multiatribut fishbein. Data yang diperoleh dan dikumpulkan kemudian dianalisis berdasarkan model yang diterapkan.

\section{HASIL DAN PEMBAHASAN}

\subsection{Gambaran Umum Responden Penelitian}

Umur responden merupakan karakteristik penduduk yang sangat penting, hal ini karena umur memiliki pengaruh terhadap aspek sosial ekonomi. Umur akan mempengaruhi setiap individu dalam berfikir dan bertindak untuk pengambilan keputusan (Rusutiadi, 2009). Pengelompokan umur dapat digolongkan sebagai berikut: usia belum produktif antara 0-14 tahun, usia produktif antara 15-64

\section{I Sikap Dan Perilaku Belanja Konsumen Minyak Goreng Kemasan Di Kecamatan Pangkalan Kerinci Kabupaten Pelalawan}


tahun, dan usia tidak produktif $\geq 65$ tahun (Tjiptoherijanto, 2011). Umur responden penelitian keseluruhannya berada pada kelompok umur produktif. Usia produktif dapat mengambil keputusan dengan baik, karena miliki sifat yang lebih terbuka dalam menerima suatu informasi dan inovasi baru. Hal ini sangat penting bagi konsumen minyak goreng yang harus bijaksana dalam pemilihan keputusan mengkonsumsi minyak goreng.

Jumlah responden yang mengkonsumsi minyak goreng kemasan dari hasil penelitian sebanyak 75 responden. Banyaknya responden yang menggunakan minyak goreng kemasan menandakan bahwa mayoritas responden telah menyadari arti pentingnya kesehatan. Berdasarkan hasil dari penelitian diperoleh motivasi responden dalam pembelian minyak goreng, kemasan hal ini dapat dilihat pada Tabel 3 .

Tabel 3. Motivasi pembelian minyak goreng responen minyak goreng kemasan

\begin{tabular}{lrr}
\hline \multirow{2}{*}{$\begin{array}{l}\text { Motivasi Pembelian Minyak } \\
\text { Goreng }\end{array}$} & \multicolumn{3}{c}{ Jenis Minyak yang Dikonsumsi Responden } \\
\cline { 2 - 3 } & Jumlah (jiwa) & Persentase (\%) \\
\cline { 2 - 3 } Harga terjangkau & 20 & 26.67 \\
Mudah diperoleh & 4 & 5.33 \\
Merupakan keputusan & 14 & 18.67 \\
rumah tangga & 37 & 49.33 \\
Untuk kesehatan & 75 & 100.00 \\
\hline Jumlah & & \\
\hline
\end{tabular}

Responden yang menggunakan minyak goreng kemasan dominan memiliki motivasi untuk kesehatan. Jumlah responden yang memiliki motivasi mengkonsumsi minyak goreng kemasan untuk kesehatan ialah sebanyak 37 responden dari 75 responden. Responden menyatakan bahwa minyak goreng kemasan lebih baik dikonsumsi daripada minyak goreng curah. Hal ini karena proses penyaringan pada minyak goreng kemasan dilakukan sebanyak dua kali dan dikemas kedalam kemasan yang memiliki merek tertentu sehingga keadaan minyak goreng kemasan tetap dalam keadaan bagus dan layak untuk dikonsumsi oleh konsumen serta aman bagi kesehatan konsumen. Sesuai dengan hasil penelitian Fitriana (2015) menunjukkan bahwa miyak goreng kemasan biasanya mempunyai mutu yang lebih tinggi dibandingkan dengan minyak goreng curah. Minyak goreng kemasan biasanya menggunakan teknologi proses yang lebih tinggi dibandingkan minyak goreng curah. Kelebihan proses produksi tersebut misalnya dilakukan dua kali penyaringan, dilakukan proses deodorisasi dan pemucatan, sehingga dihasilkan minyak goreng yang lebih jernih dan tidak berbau.

58 I Sikap Dan Perilaku Belanja Konsumen Minyak Goreng Kemasan Di Kecamatan Pangkalan Kerinci Kabupaten Pelalawan 


\subsection{Analisis Sikap Konsumen terhadap Produk Minyak Goreng Kemasan}

Sikap pada konsumen yang mengggunakan minyak goreng kemasan dipengaruhi oleh atributatribut yang dimiliki oleh minyak goreng kemasan. Sikap terhadap objek pembelian minyak goreng kemasan akan dikaitkan dengan perilaku terhadap objek pembelian produk minyak goreng kemasan. Sikap konsumen terhadap produk minyak goreng kemasan di Kecamatan Pangkalan Kerinci dapat dilihat pada Tabel 4.

Tabel 4. Sikap konsumen terhadap produk minyak goreng kemasan di Kecamatan Pangkalan Kerinci $(\mathrm{AB})$

\begin{tabular}{llrrr}
\hline \multirow{2}{*}{ No } & Atribut minyak goreng kemasan & Keyakinan (bi) & Evaluasi (ei) & AB (bi x ei) \\
\hline 1 & Harga yang murah & 1.08 & 1.17 & 1.27 \\
2 & Warna yang jernih & 1.27 & 1.85 & 2.35 \\
3 & Higienis & 1.21 & 2.08 & 2.52 \\
4 & Ukuran bervariasi & 1.84 & 2.33 & 4.29 \\
5 & Praktis & 1.60 & 2.28 & 3.65 \\
6 & Kandungan terjaga & 1.36 & 2.31 & 3.14 \\
\hline \multicolumn{2}{c}{ Nilai Sikap Konsumen } \\
\hline
\end{tabular}

Berdasarkan Tabel 4 menunjukkan bahwa sikap konsumen terhadap produk minyak goreng kemasan bernilai 17,22 sehingga menunjukkan bahwa sikap konsumen terhadap atribut minyak goreng kemasan ialah baik karena bernilai positif. Menurut Churchill (2005), secara umum jika seseorang memiliki sikap yang positif terhadap suatu produk atau merek, maka orang itu lebih mungkin memilih dan membeli produk atau merek tersebut. Pada nilai keyakinan (bi) atribut ukuran bervariasi menjadi pertimbangan utama bagi konsumen dan setelah dievaluasi pada nilai evaluasi (ei) atribut ukuran bervariasi juga menjadi pertimbangan utama bagi konsumen dengan nilai masing-masing ialah 1,84 dan 2,33 . Oleh karena itu yang menjadi pertimbangan utama bagi konsumen dalam mengkonsumsi minyak goreng kemasan ialah ukuran yang bervariasi dari minyak goreng kemasan. Hal ini terbukti dari ukuran minyak goreng kemasan yang beredar dipasaran pada masa sekarang sudah mulai beragam dengan bentuk kemasan yang praktis. Adapun besaran nilai yang diperoleh dari sikap konsumen terhadap atribut ukuran bervariasi dari minyak goreng kemasan ialah 4,29.

Ditinjau berdasarkan acuan pada Tabel 2, dapat dilihat hasil dari nilai sikap konsumen dengan nilai 17,22 berarti bahwa nilai sikap konsumen terhadap minyak goreng kemasan di Kecamatan Pangkalan Kerinci berada pada rentang nilai $0<\mathrm{AB} \leq 18$ dengan kategori cukup baik. Sehingga

\section{I Sikap Dan Perilaku Belanja Konsumen Minyak Goreng Kemasan Di Kecamatan} Pangkalan Kerinci Kabupaten Pelalawan 
dapat disimpulkan secara keseluruhan sikap konsumen terhadap atribut produk minyak goreng kemasan bernilai 17,22 mempunyai sikap yang cukup baik

\subsection{Analisis Norma Subjektif Konsumen Terhadap Produk Minyak Goreng Kemasan}

Norma subjektif konsumen terhadap pembelian minyak goreng kemasan di Kecamatan Pangkalan Kerinci dapat dilihat pada Tabel 5.

Tabel 5. Norma subjektif konsumen terhadap minyak goreng kemasan di Kecamatan Pangkalan Kerinci

\begin{tabular}{clccc}
\hline No & Referen & $\begin{array}{c}\text { Keyakinan } \\
\text { Normatif }(\mathrm{NBj})\end{array}$ & $\begin{array}{c}\text { Motivasi } \\
(\mathrm{MCj})\end{array}$ & SN (NBj x MCj) \\
\hline 1 & Masyarakat sekitar & -1.64 & -1.81 & 2.97 \\
2 & Kebijakan pemerintah & -1.65 & -0.43 & 0.71 \\
\hline \multicolumn{5}{c}{ Norma Subjektif Konsumen } \\
\hline
\end{tabular}

Berdasarkan Tabel 5, diperoleh nilai keyakinan normatif untuk referen masyarakat sekitar sebesar -1,64 sedangkan untuk referen kebijakan pemerintah diperoleh nilai sebesar -1,65. Hal ini berarti keyakinan konsumen terhadap produk minyak goreng kemasan tidak dipengaruhi oleh referen masyarakat sekitar dan kebijakan pemerintah. Nilai motivasi tidak dipengaruhi atau tidak timbul karena masyarakat sekitar dan kebijakan pemerintah. Hal ini dikarenakan nilai motivasi pada referen masyarakat sekitar bernilai -1,81 dan nilai motivasi pada referen kebijakan pemerintah bernilai $-0,43$.

Norma subjektif konsumen terhadap minyak goreng kemasan bernilai positif dengan nilai 3,68. Berarti secara keseluruhan referen masyarakat sekitar dan referen kebijakan pemerintah menjadi acuan kosumen dalam membeli minyak goreng kemasan. Sebelumnya nilai referen masyarakat dan kebijakan bernilai negatif untuk variabel keyakinan normatif dan motivasi. Namun setelah dilakukan perkalian secara sistematis antara keyakinan normatif yang bernilai negatif dengan motivasi yang juga bernilai negatif maka hasil yang diperoleh yaitu positif. Jadi artinya referen masyarakat sekitar dan kebijakan pemerintah yang sebelumnya tidak mempengaruhi konsumen dalam membeli minyak goreng kemasan menjadi referen yang mempengaruhi atau menjadi acuan bagi konsumen dalam membeli minyak goreng kemasan. Hasil penelitian ini sesuai dengan hasil penelitian Putri (2014) menunjukkan bahwa nilai yang ditunjukkan oleh masingmasing referen adalah positif, sehingga artinya dalam pengambilan keputusan konsumen mempertimbangkan referen legalitas produk dan pengaruh orang sekitar.

\subsection{Analisis Perilaku Konsumen Terhadap Produk Minyak Goreng Kemasan}

60 I Sikap Dan Perilaku Belanja Konsumen Minyak Goreng Kemasan Di Kecamatan Pangkalan Kerinci Kabupaten Pelalawan 
Berdasarkan skor jawaban responden dari konsumen yang mengkonsumsi minyak goreng kemasan terhadap norma subjektif, dapat dihitung bobot empiris menggunakan persentase rata-rata. Bobot empiris sikap dan norma subjektif konsumen minyak goreng kemasan dapat dilihat pada Tabel 6.

Tabel 6. Bobot empiris sikap (W1) dan norma subjektif (W2) konsumen minyak goreng kemasan

\begin{tabular}{cccc}
\hline W1 & Persentase & W2 & Persentase \\
\hline 60 & 80 & 15 & 20 \\
60 & 80 & 15 & 20 \\
62 & 82.67 & 13 & 17.33 \\
40 & 53.33 & 35 & 46.67 \\
\hline Rata-rata & 74 & Rata-rata & 26 \\
\hline
\end{tabular}

Berdasarkan Tabel 6, diperoleh nilai W1 > W2 $(74>26)$, W1 lebih berperan dalam pembentukan maksud perilaku. Hal ini berarti pembelian minyak goreng kemasan oleh konsumen dalam pengambilan keputusan lebih banyak dipengaruhi oleh diri sendiri atau karena kesadaran yang timbul dari pribadi konsumen itu sendiri. Dapat juga dikatakan bahwa referen (masyarakat sekitar dan kebijakan pemerintah) tidak mempengaruhi pembelian konsumen minyak goreng kemasan.

Dalam hal ini, persamaan Fishbein yang akan digunakan untuk memprediksi perilaku konsumen dalam membeli minyak goreng kemasan di Kecamatan Pangkalan Kerinci adalah sebagai berikut :

$$
\begin{aligned}
& \mathrm{BI}=\mathrm{W} 1(\mathrm{AB})+\mathrm{W} 2(\mathrm{SN}) \\
& \mathrm{BI}=74(17,22)+26(3,68) \\
& \mathrm{BI}=2.107,52+95,68 \\
& \mathrm{BI}=1.369,97
\end{aligned}
$$

Jika nilai BI > 0 maka perilaku konsumen terhadap produk minyak goreng kemasan adalah baik, sedangkan jika nilai BI < 0 maka perilaku konsumen terhadap produk minyak goreng kemasan adalah tidak baik. Berdasarkan hasil perhitungan dari persamaan Fishbein, dikatakan perilaku konsumen terhadap produk minyak goreng kemasan adalah baik. Hal ini dikarenakan nilai BI >0, adapun nilai BI yang diperoleh ialah 1.369,97. Seperti yang dinyatakan Umar (2000), nilai BI positif menunjukkan perilaku pembelian konsumen cukup baik. Berarti dapat disimpulkan bahwa perilaku konsumen dalam membeli minyak goreng kemasan di Kecamatan Pangkalan Kerinci cukup tinggi. Semakin besar nilai positif yang diperoleh, maka perilaku konsumen terhadap suatu produk, yakni minyak goreng kemasan akan semakin baik.

\section{I Sikap Dan Perilaku Belanja Konsumen Minyak Goreng Kemasan Di Kecamatan} Pangkalan Kerinci Kabupaten Pelalawan 


\section{KESIMPULAN}

Berdasarkan hasil penelitian yang sudah dilakukan, maka dapat disimpulkan bahwa

1. Sikap konsumen minyak goreng terhadap pembelian produk minyak goreng kemasan bernilai positif. Adapun nilai sikap konsumen minyak goreng kemasan ialah 17,22 dan atribut ukuran bervariasi menjadi pertimbangan utama. Nilai positif yang diperoleh menunjukan bahwa secara keseluruhan konsumen mempunyai sikap yang baik terhadap seluruh atribut yang terdapat pada minyak goreng kemasan.

2. Perilaku konsumen terhadap pembelian minyak goreng kemasan bernilai $1.369,97$. Nilai positif (BI > 0) yang diperoleh menunjukkan bahwa perilaku belanja konsumen terhadap minyak goreng kemasan adalah baik.

\section{DAFTAR PUSTAKA}

Badan Pusat Statistik Kabupaten Pelalawan. 2018. Kabupaten Pelalawan Dalam Angka 2018. BPS Kabupaten Pelalawan. Pangkalan Kerinci.

Badan Pusat Statistik Kabupaten Pelalawan. 2018. Kecamatan Pangkalan Kerinci Dalam Angka 2016. BPS Kabupaten Pelalawan. Pangkalan Kerinci.

Churchill, 2005. Dasar-Dasar Riset Pemasaran. Jilid I. Edisi ke 4. Erlangga. Jakarta.

Departemen Pertanian, Direktorat Jendral Perkebunan. 2015. Statistik Perkebunan Indonesia 20142016 : Kelapa Sawit (Oil Palm). Sekretariat Direktorat Jenderal Perkebunan. Jakarta.

Direktorat Jendral Perkebunan. 2016. Statistik Perkebunan Indonesia 2015-2017 : Kelapa Sawit (Oil Palm). Sekretariat Direktorat Jendral Perkebunan. Jakarta.

Fauzi, Yan. 2008. Kelapa Sawit: Budi Daya, Pemanfaatan Hasil dan Limbah, Analisis Usaha dan Pemasaran. Cetakan 24. Penebar Swadaya. Jakarta.

Fitriana. 2015. Analisis Perbandingan Sikap Konsumen dalam Memilih Produk Minyak Goreng Kemasan dan Curah (Studi Kasus Ibu Rumah Tangga di Kota Pekanbaru). Jurnal Online Mahasiswa Fakultas Ekonomi. 2(1) : 1-14.

Kotler, Philip dan Armstrong. 2001. Prinsip-Prinsip Pemasaran. Jilid 1. Edisi ke 8. Erlangga. Jakarta.

62 I Sikap Dan Perilaku Belanja Konsumen Minyak Goreng Kemasan Di Kecamatan Pangkalan Kerinci Kabupaten Pelalawan 
Kukuh. 2010. Minyak Goreng yang Baik Tersedia www.kompasiana.com. Diakses tanggal 25 November 2017.

Putri. 2014. Analisis Perilaku Konsumen terhdap Pembelian Jamur Tiram du Kota Pekanbaru. Jurnal Online Mahasiswa Bidang Pertanian. 1(2) : 1-13.

Primadhyta Safyra. 2016. Mendag Tunda Kewajiban Penjualan Minyak Goreng Kemasan. CNN Indonesia.16 Februari 2016.

Rustiadi, Ernan, S. Saefulhakim, dan D.R. Panaju. Perencanaan dan Pengembangan Wilayah. Yayasan Pustaka Obor Indonesia. Jakarta.

Supriyana, Eko. 2006. Analisis Faktor-faktor yang Mempengaruhi Perilaku Konsumen dalam Pembelian Minyak Goreng Bermerek dan Tidak Bermerek (Kasus: Rumah Makan di Kota Bogor). Skripsi (Tidak dipublikasikan). Fakultas Pertanian, Institut Pertanian Bogor.

Tambun, Rondang. 2006. Teknologi Oleokimia. Departemen Teknik Kimia Fakultas Teknik Universitas Sumatera Utara. Medan.

Tjiptoherijanto, Prijono. 2011. Proyeksi Penduduk, Angkatan Kerja, Tenaga Kerja dan Peran Serikat Pekerja dalam Peningkatan Kesejahteraan. Majalah Perencanaan Pembangunan. Edisi 23 tahun 2001.

Umar, Husein. 2000. Riset Pemasaran dan Penilaian Konsumen. PT. Gramedia Pustaka. Jakarta.

63 I Sikap Dan Perilaku Belanja Konsumen Minyak Goreng Kemasan Di Kecamatan Pangkalan Kerinci Kabupaten Pelalawan 
64 Sikap dan Perilaku Belanja Konsumen Minyak Goreng Kemasan di Kecamatan Pangkalan Kerinci Kabupaten Pelalawan 